\title{
As aventuras de Ngunga, de Pepetela: muito além da cartilha
}

\author{
Thiago Lauriti
}

Universidade de São Paulo

livro As aventuras de Ngunga foi escrito em 1972 pelo escritor angolano Artur Pestana - o Pepetela - e publicado um ano depois, em forma mimeografada em plena floresta do Leste de Angola pelos serviços de cultura do MPLA. O próprio autor declara que esse livro não nasceu de uma necessidade estética, mas da constatação de que o ensino nas escolas de base do MPLA requeriam textos de apoio que pudessem ser lidos em sua própria língua - o Mbunda. Em posse dos registros resultantes de suas incursões pelos acampamentos do MPLA para verificar o número de combatentes e de armas, percebeu que dados poderiam constituir cumprir tal função. $\mathrm{E}$ assim surgiram $A$ s aventuras de Ngunga "[...] Quando acabei cheguei à conclusão que aquilo era uma estória, dei-lhe um fio condutor e mais tarde decidimos publicá-lo".

Essa motivação inicial declarada, entretanto, não implicou o esvaziamento do compromisso de Pepetela com a arte ou a redução do valor de sua obra que a etimologia do signo cartilha (carta + ilha, pelo espanhol cartilla) pode sugerir, se entendida como primeiros rudimentos para aprender a ler. A leitura atenta da obra evidencia ao leitor que o seu projeto inicialmente ideológico-pragmático desdobrou-se em um projeto estético capaz de dar voz aos angolanos - herdeiros do silêncio e mostrar que Ngunga sobrevive em todos aqueles que recusam a injustiça e a opressão.

Dessa forma, três vertentes entrecruzam-se nessa obra de Pepetela: sua ação bélica enquanto combatente do MPLA, seu projeto ideológico de colo-

1 Conforme o depoimento publicado pela Universidade de Lisboa através do Centro de Investigação para Tecnologias Interativas (CITI). Disponível em: http://www.citi.pt/cultura/literatura/romance/ pepetela/ngunga.html. Acesso em: 10/03/2009. 
car no universo imaginativo de crianças e jovens a dura realidade das guerrilhas para conseguir adesão à causa revolucionária e o seu projeto estético de criação literária o que efetivamente cumpriu.

O fio condutor que alinhava a tessitura da narrativa é o rito de passagem por que passa o pequeno protagonista - Ngunga - por meio das viagens que faz pelos bastidores da luta armada em Angola, lócus privilegiado para a metaforização das experiências de aprendizagem da identidade nacional angolana, da qual ele vai se tornar o modelo. É a história de Ngunga que reinventa a História de Angola. Por essa razão metaforiza-se uma saga de amadurecimento do protagonista que sonha tornar-se guerrilheiro, mas desencanta-se com a realidade que vai conhecendo gradativamente. Pode-se dizer que Ngunga não é, ele apresenta-se como um vir a ser, um devir-criança que constrói seu itinerário no mundo pelas suas escolhas e ações.

A narrativa concentra-se na trajetória de Ngunga, um órfão de treze anos, que teve os pais assassinados pelos colonialistas e vaga errante de aldeia em aldeia, canalizando todos os seus movimentos e forças para a aposta política de tornar-se um guerrilheiro. Situa-se com intensidade nesse universo, colocando-se em permanente estado de viajante nômade que precisa conhecer o mundo e tornar-se homem para ser validado pelo mundo adulto. Essa metafórica travessia corporifica a imagem da infância mais como condição do que como uma fase, mais como uma dimensão do que como etapa que se nutre da experiência com a realidade configurando-se como um devir-criança pela ação da desmistificação de valores, da ruptura da história, da revolução e da criação de mecanismos de resistência. É esse devir-criança que autoriza sua errância, o situar-se sempre em diferentes lugares para interromper a história e resgatar uma outra temporalidade, aquela que o pensamento grego denomina aión, vale dizer, o tempo da intensidade das experiências humanas, do destino e das vivências intensas.

A busca do pequeno Ngunga é pelo autoconhecimento, pela aprendizagem, pela compreensão dos valores revolucionários e para tal são necessárias a peregrinação, a experiência das ações vividas, a tomada de consciência da realidade, que metaforiza o trajeto por que deve passar também Angola para atingir a maturidade.

No espelho ficcional, em seu trajeto de aldeia em aldeia, Ngunga convive com uma galeria de atores que habitam duas dimensões distintas na teia 
discursiva: o universo infantil que é idealizado, bom, inocente e utópico confrontando-se com o universo que retrata a realidade do mundo adulto por isso oferece lições de injustiça, de mentira, de inveja e de exploração.

$\mathrm{Na}$ esfera do mundo adulto sua primeira experiência de desencanto ocorre com o Presidente Kafuxi que o acolhe em sua aldeia em troca de trabalho, mas a proximidade com esse líder do movimento o revela como um homem mesquinho, egoísta e dissimulado que escondia o alimento dos guerrilheiros a quem devia ajudar. "Todos adultos eram assim egoístas? [...] Só pensavam neles? Até mesmo um chefe do povo, escolhido pelo Movimento para dirigir o povo. Estava certo?” (PEPETELA, 1980: 15). Sucedem-se as decepções a cada incursão do protagonista no universo adulto e a geografia dos costumes, das tradições e do cotidiano da guerrilha vai sendo desvelada pelo olhar do próprio colonizado, já que ele entende e engaja-se à luta do seu povo, mas ao conhecê-la de perto desencanta-se, sem contudo abandonar o seu sonho. "Tudo que era bom era oprimido e esmagado pelo que era feio e mal." (PEPETELA, 1980: 52). Povoam o universo idealizado infantil, identificado com a virtude, com a inocência e com os ideais do projeto revolucionário: o próprio Ngunga, a pequena Imba, a inocente filha de Kafuxi que é vendida pelo pai e Uassamba, a bonita menina de treze anos, casada com o velho Chipoya o que a impede de concretizar a paixão proibida por Ngunga. Interessante observar que não é o chrónos que define a inserção desses personagens em uma ou em outra dimensão discursiva, mas o aión, isto é, o tempo das ações vivenciadas. Por essa razão, o amigo do protagonista - Nossa Luta - que morreu pela causa revolucionária e torna-se símbolo dela e o Professor União que se recusou a delatar os companheiros revolucionários e por isso foi capturado e preso, apesar de serem adultos, têm a permissão de integrar-se ao universo valorativo infantil, pois guardam a inocência e a bondade. Já Chivuala, o também órfão de quinze anos que estudava com Ngunga, não consegue pertencer a essa dimensão, pois “O Chivuala já é quase um homem. É por isso que começa a ficar mau e invejoso.” (PEPETELA, 1980: 29).

Da dimensão da realidade do universo adulto participam todos os atores que, em decorrência de algum comportamento questionável, afastam-se do ideal da revolução. Pertencem a essa categoria o mesquinho presidente da aldeia - Kafuxi -, o orgulhoso Comandante Mavinga que sempre aumentava seus feitos na guerrilha, o invejoso Comandante Avança, o traidor Chitangua que indicou 
aos colonialistas o caminho da escola para que ela fosse atacada pelos colonialistas, o agente da PIDE responsável pelas operações de ataque às aldeias e o cozinheiro que o servia como criado, o velho Chipoya que comprou Uassamba para casar-se com ela, cumprindo a tradição do alambamento, e os tugas, forma como são nomeados os colonialistas, o inimigo comum que aparece no enredo como figuração sem merecer sequer o estatuto de personagem.

Ngunga aprende a ler o mundo da revolução pelo filtro dessas experiências que revelam a realidade da guerrilha, o ranço de algumas tradições angolanas e os vícios e pequenezas desses personagens. Esses elementos constituem-se como vetores do amadurecimento do protagonista em estado de devir-criança, porque o fazem pensar, observar, comparar, inferir, concluir, questionar, criticar e relativizar o estatuto de líder que é conferido a esses adultos: "Tinha vontade de gritar, de insultar o Chipoya, os pais de Uassamba, os velhos que defendiam os costumes cruéis, os novos que não tinham coragem de os destruir." (PEPETELA, 1980: 55).

Ngunga é, dessa forma, porta voz de uma idéia recorrente em Pepetela que aponta para a necessária desconstrução de valores da tradição da sociedade africana que entraram em decomposição para que se torne possível a construção da identidade de uma nova nação (o devir-Angola), que possa ser incorporada pelas novas gerações que devem continuar o projeto político e tornar Angola liberta do jugo português.

O discurso do protagonista, em várias passagens, deixa claro que o universo dos novos e dos velhos não se polarizam e por isso não se neutralizam em verdades específicas, pois é do contato inevitável entre essas duas esferas inter-relacionadas que vem a força que alimenta a luta contra o inimigo comum - os colonialistas - e a opressão que eles representam. A causa revolucionária sobrepõe-se a tudo e permite que as tradições do passado possam ser revisitadas em nome do futuro que aguarda ser construído e cessam as dualidades. "As pessoas de quem gostava e de quem não gostava vinham-lhe à lembrança: os pais, Mussango, Kafuxi, Imba, Nossa Luta, Mavinga, Chivuala, União. Bons ou maus, todos tinham uma coisa boa: recusavam ser escravos, não aceitavam o patrão colonialista." (PEPETELA, 1980: 41).

Desaparece, assim, a linha tênue que separa os heróis dos vilões ou o universo infantil do adulto, pois é o rito de passagem enquanto ato existencial, do devir-Ngunga o elemento necessário para transformar o menino em homem que 
precisa ser preservado. Esse é o fio condutor que atravessa o enredo para encenar a viagem transformadora do protagonista, desenhar sua geografia interior e metaforizar a infância como substratum das utopias e dos sonhos políticos.

Pepetela concretiza, em As aventuras de Ngunga, um projeto estético que vai além do seu projeto político e do tom cartilhesco com matiz de palavra de ordem. "Nunca te esqueças de que és um pioneiro do MPLA. Luta onde estiveres!” (PEPETELA, 1980: 38). O autor propõe a si próprio e ao seu leitor a necessidade da conscientização do ser-estar angolano naquele momento histórico, que carrega o pressentimento da esperança de que nos fala Ernst Bloch. Esse princípio delineia-se não apenas na efabulação, mas revela-o como um embrião da utopia que vai sendo gestada e prepara a construção do futuro de Angola. É a esperança na transformação que modula os movimentos de Ngunga e o ajuda a superar as contradições históricas que presencia durante seu ato libertador, pois percebe que os vícios que conhece durante a viagem estão inscritos na alma humana e não na causa política. Experimentá-los ou não é uma opção de cada sujeito histórico em sua travessia.

No cenário textual, a floresta com todos os seus elementos é um espaço cúmplice que presencia a trajetória das aprendizagens humanas, estabelecendo uma relação dinâmica com Ngunga. É ao mesmo tempo fonte de alimento, de proteção e de liberdade; lugar onde ele aprende a matar; o roteiro obrigatório de suas descobertas, o palco idílico que testemunha a descoberta do amor e o maior momento em que "Um homem tinha nascido dentro do pequeno Ngunga.” (PEPETELA, 1980: 57). O devir, entretanto, não cessa, porque o protagonista resolve mudar de nome e partir sozinho para a escola, porque percebe que o conhecimento é a única forma de reafirmar a revolução, considerando que acima do amor de Uassamba e de todas as outras pulsões e desejos está o ideal revolucionário. Contracenando com esse espaço está uma voz narrativa nômade como o pequeno protagonista que, em alguns momentos, afasta-se e, em outros, mistura-se ao conteúdo narrado. Já no capítulo final - "Para terminar" - penetrando nos pensamentos de Ngunga pelo discurso indireto livre, essa voz assume-se polifonicamente como um 'griot" que quer manter viva as histórias na História. "Esta história de Ngunga foi-me contada por várias pessoas, nem sempre da mesma maneira.” (PEPETELA, 1980: 57).

Fugindo das conclusões que os epílogos contêm, a narrativa abre-se para a dúvida que eterniza a condição devir de Ngunga. A voz do narrador como 
estratégia discursiva para convencer o leitor da verdade factual da narrativa interpela "Camarada pioneiro: Procurei em todas as escolas, a ver se encontrava o Ngunga. Mas foi em vão.” (PEPETELA, 1980: 57). Nenhuma das personagens - Uassamba, Mavinga, Kafuxi e nem mesmo os pássaros da floresta - puderam dar informações sobre Ngunga, porque já estavam imersos na sucessão do tempo que sempre e a tudo transforma: o ritmo da História já havia transformado suas histórias. Em um segundo apelo, bem mais persuasivo, a voz narrativa faz com que Ngunga escape do cenário ficcional e possa continuar sua viagem no plano factual em qualquer lugar: "Vê bem, camarada pioneiro. Talvez esse camarada que contigo estuda, contigo come, contigo brinca, seja o Ngunga. Ou talvez Ngunga já não seja pioneiro. Será então guerrilheiro, como desejava.” (PEPETELA, 1980: 59).

O movimento crescente de procura continua... "Camarada guerrilheiro, vê bem o jovem combatente que a teu lado se encontra? Não será Ngunga [...] esse guerrilheiro que quer acabar com todas as injustiças venham elas de onde vierem e mudar o mundo? (PEPETELA, 1980: 59) até chegar ao grau máximo da expansão: "Não será numa parte desconhecida de ti próprio que se esconde modestamente o pequeno Ngunga? Ou talvez Ngunga tivesse um poder misterioso e esteja agora dentro de todos nós, nós os que recusamos viver no arame farpado, nós os que recusamos o mundo dos patrões e dos criados, nós os que queremos o mel para todos." (PEPETELA, 1980: 59). Esse movimento narrativo do último capítulo confere uma força conativa à obra e reflete um processo de organização das consciências, aspecto tão recorrente na obra de Pepetela, ao lado da idéia de ciclos. E se "Portanto, só os ciclos eram eternos" (PEPETELA, 1993: 11), pode-se imaginar que o pequeno Ngunga cumpriu seu ciclo nessa obra, mas tendo tornado-se homem, imerso na inexorabilidade do tempo, poderá ressurgir em outros espaços, em outros tempos, em outras histórias...

\section{Referências Bibliográficas}

PEPETELA. As aventuras de Ngunga. São Paulo: Ática, 1980. . A geração da utopia. Lisboa: Dom Quixote, 1993. 